\title{
An eco-friendly and low-cost strategy for groundwater defluorination: Adsorption of fluoride onto calcinated sludge
}

Renata S. Pigatto; Dison S. P. Franco; Matias S. Netto; Élvis Carissimi; Luis F. S. Oliveira; Sérgio L. Jahn; Guilherme L. Dotto

\begin{abstract}
The excess of fluoride ions ( $\mathrm{F}-$ ) in water for human supply is a serious public health. The recommended concentration of $\mathrm{F}$ - ions by the World Health Organization (WHO) is $1.5 \mathrm{mg} \mathrm{L}^{-1}$. Several groundwater sources around the world contain high $\mathrm{F}$ - concentrations, and require treatment before human consumption. It was developed an eco-friendly and lowcost strategy for groundwater defluorination, i.e., adsorption onto calcinated sludge. This strategy was efficient at $\mathrm{pH}$ of 5.5 and using $5 \mathrm{~g} \mathrm{~L}$ ${ }^{1}$ of calcinated sludge. The groundwater attained the WHO standard within 60 min. The kinetic model of pseudo-second-order obtained a better adjustment to the experimental data. The equilibrium curve at $25{ }^{\circ} \mathrm{C}$ was better represented by the Tóth model. The maximum adsorption capacity was $2.04 \mathrm{mg} \mathrm{g}^{-1}$. Therefore, adsorption using calcinated sludge can be considered as an eco-friendly and low-cost strategy for groundwater defluorination.
\end{abstract}

Keywords

Adsorption; Defluorination; Water treatment; World Health Organization 